Vol. 4, No. 2, Oktober 2020, hlm. 303-324

DOI: $10.37274 /$ rais.v4i02.343

\title{
Implementasi Adab Berdialog Menurut Muhammad Sayyid Thanthawi Melalui Pembelajaran Siswa Aktif
}

\author{
Moh. Erfan Maulana1 ${ }^{*}$, Abuddin Nata1,2, Adian Husaini' ${ }^{1}$,E.Bahruddin'1 \\ ${ }^{1}$ Universitas Ibn Khaldun Bogor, Indonesia \\ ${ }^{2}$ Universitas Islam Negeri Jakarta, Indonesia \\ *erfan.mesir@gmail.com
}

\begin{abstract}
Abstrak
Dialog merupakan salah satu metode pembelajaran yang melibatkan peserta didik untuk aktif, baik secara kognitif, afektif, maupun psikomotorik. Namun dalam prakteknya dialog tekadang mengarah kepada sikap saling bertentangan dan memancing emosi. Penelitian ini bertujuan untuk mengetahui konsep berdialog menurut Muhammad Sayyid Tantawi dalam kitabnya, Adab Hiwar fi al-Islam, serta implementasinya ke dalam pembelajaran aktif di sekolah. Temuan dari penelitian ini diantaranya adalah adab berdialog menurut Muhammad Sayyid Tantawi terdiri dari sebelas kaidah, yaitu, kejujuran, fokus pada tema yang dibahas, menghadirkan dalil akurat dan logika sehat, memperjelas letak perbedaan, etika kesantunan, menghindari perbuatan yang zhalim, mengarah pada kepentingan umum, mendahulukan pendapat para pakar, tidak menjeneralisir hukum, meninjau asas manfaat dan madharatnya, meningkatkan pemahaman dan akurasi hukum yang disepakati para ahli, terbuka dan apa adanya, dengan mengedepankan kebenaran. Pemikiran Muhamad Sayyid Thanthawi tentang adab berdialog ini dapat diimplementasikan secara strategis-konseptual ke dalam pembelajaran aktif di sekolah dimana salah satunya adalah melalui Rencana Perangkat Pembelajaran (RPP) dengan menginternalisasikan dasar pijakan pembelajaran aktif yang diusung oleh L. Dee Fink, yaitu: Dimensi Pengetahuan Dasar, Dimensi Penerapan, Dimensi Penyatuan, Dimensi Kemanusiaan: belajar tentang dan perubahan diri seseorang, Dimensi Kasih sayang: mengidentifikasi/perubahan perasaan, dan Dimensi Belajar untuk belajar.
\end{abstract}

Kata kunci: Active learning; Civilized dialogue; Islamic Teaching Values

\begin{abstract}
Dialogue is a method of learning that involves students to be active, both cognitive, affective, and psychomotoric. But in practice dialogue sometimes leads to conflicting attitudes and provoking emotions. This study is aimed to explore dialogue concept of Muhammad Sayyid Tantawi in his book Adab Hiwar fi al-Islam and the implementation of the dialogue concept into active learning at school. The finding showed that there are eleven rules of dialogue concept which according to Muhammad Sayyid Tantawi, namely: (1) Honesty, (2) Focus on the themes discussed, (3) Presenting an accurate proposition and sound logic (4) Clarify the location of differences in a concrete and correct manner according to the discussion (5) Ethics of politeness, avoiding actions that are not appropriate to do, (6) Lead to the public interest, (7) Prioritize the opinions of expert experts, (8) Do not generalize the law, (9) Reviewing the principles of benefits and their disadvantages, (10)
\end{abstract}




\section{Maulana, Nata \& Bahruddin}

Upgrading the understanding and accuracy of the law agreed upon by the experts (11) Being open and candid, by promoting the truth.

Keywords: Active learning; Civilized dialogue; Islamic Teaching Values

\section{Pendahuluan}

Keseluruhan proses yang dilakukan dan terjadi dalam pendidikan ditujukan untuk menghasilkan nilai atau sifat kemanusiaan berupa sikap dan perilaku yang kemudian menjadi watak, kepribadian, budi pekerti, etika, moral atau karakter, yang dalam perspektif Islam dapat disebut dengan istilah akhlak atau adab. Selain diusahakan secara pribadi dan di dalam ranah keluarga, pendidikan juga merupakan proses pengubahan sikap dan tata laku seseorang atau kelompok orang dalam usaha mendewasakan manusia melalui upaya pengajaran dan pelatihan; proses, cara, perbuatan mendidik (Departemen Pendidikan Nasional, 2012). Oleh karenanya, aspek proses pendidikan sangat luas dan beragam, mencakup aspek jasmani (psikomotorik) (Santrock, 2007; Yaumi, 2013), akal (kognitif) (Dimyati dan Mudjiono, 2009; Winkel, 1987), dan hati (afektif) (Dimyati dan Mudjiono, 2009; Winkel, 1987) dengan berbagai macam varian yang dilakukan di dalam dan di luar sekolah dalam makna yang luas.

Meski demikian dari sisi positif sebagai hasil penerapan pendidikan di Indonesia, ternyata muncul banyak gejala negatif yang timbul pada ranah transformasi pendidikan. Ilmu-ilmu produk ilmuwan barat menimbulkan persoalan pelik yang tidak menguntungkan bagi pandangan Muslim, persoalan utamanya adalah pergeseran paradigama ilmu. Epistemologi yang digunakan dalam proses mendapatkan ilmu adalah epistemologi rasional-empiris -membuang dimensi metafisik (Al-Attas, 1995). Selain itu, tendensi moral (baca: adab) mengalahi krisis yang luar biasa baik dikalangan peserta didik maupun dikalangan mahasiswa. Di kota-kota besar sering terjadi corat-coret tembok dengan kalimat yang tidak santun, tawuran masal yang dimulai dari aksi bullying, basis-basis geng sekolah, maraknya seks bebas (free sex), Narkoba, minum-minuman keras, hingga terorisme. Apalagi masalah sopan santun yang telah lama memudar dari kehidupan mereka. Belum lagi seperti adanya supporter sepak bola seusai pertandingan memadati jalan raya dengan mengendarai sepeda motor dan tidak memberi kesempatan pengendara lain untuk sekedar lewat. Bahkan, mereka seringkali menggebrak-gebrak kendaraan milik orang lain dengan tangan, pentungan, dan bendera simbol klub kebanggaannya (Al-Attas, 1995), bila dicermati lebih jauh, problematika pendidikan ini akan semakin banyak kasusnya.

Di sisi lain, model pembelajaran dalam Islam sangatlah kental dengan nuansa dialogis, sehingga lulusan pembelajarnya diarahkan untuk dapat menjadi insan yang bertaqwa searah dengan tujuan pendidikan nasional (Tafsir, 2014). Pendidikan hendaknya mengarahkan pada situasi belajar yang saling menemani, saling belajar dalam 
kehidupan sehingga memungkinkan terjadinya dialog adalah untuk membuka wawasan kehidupan masyarakat (Azra, 2012). Pembelajaran aktif dalam kurikulum 2013 sangat dominan tingkat memorisasinya, sehingga penyerapan pengetahuan dapat terinteraksi secara optimal melalui proses partisipasi sebanyak 90\% (Kemenristek Dikti, 2019). Beberapa penelitian membuktikan bahwa perhatian anak didik berkurang bersamaan dengan berlalunya waktu. Penelitian Pollio (1984) menunjukkan bahwa siswa dalam ruang kelas hanya memperhatikan pelajaran sekitar 40\% dari waktu pembelajaran yang tersedia. Sementara penelitian McKeachie (1986) menyebutkan bahwa dalam sepuluh menit pertama perthatian siswa dapat mencapai 70\%, dan berkurang sampai menjadi 20\% pada waktu 20 menit terakhir (Amri, 2013). Penambahan visual pada proses pembelajaran dapat menaikkan ingatan sampai 171\% dari ingatan semula (Amri, 2013). Oleh karenanya, implementasi ada berdialog dalam proses pembelajaran aktif menjadi sangat penting untuk meminimalisir kegagalan dalam proses belajar mengajar.

Menjawab persoalan ini, Thanthawy telah lebih dulu menyelesaikan tujuh ribu halaman penafsiran Al-Qur'an (Al-tafser al-waset). Tafsir yang memerlukan waktu sepuluh tahun masa penyelesaian ini meletakkan dasar-dasar dialog dan debat, diskusi dan review antara manusia dalam hal-hal tertentu, yang mana menurutnya kata dialogis telah diulang dalam alQur'an, lebih dari 1.700 kali. Sehingga dirasa perlu dan penting untuk mengangkat kembali tema dialogis khususnya pada dunia pendidikan.

Berdasarkan penelusuran literatur terkait dengan tema bahasan, tokoh dan kitab edukatifnya, ditemukan beberapa penelitian ilmiah-akademik yang mengangkat tema atau pembahasan yang serupa. Penelitian yang dilakukan oleh Hidayat (2019) memparkan konsep pendidikan berbasis Adab menurut A.Hassan. Selain itu, Adiyansyah (2016) telah lebih dulu mengangkat tema adab dalam pendidikan Islam, yaitu konsep Adab Said Muhammad Naguib Alatas dan aplikasinya di perguruan tinggi Penelitian ini bertujuan untuk mengkaji konsep adab said muhammad naked alatas kemudian mengkaji aplikasinya di Internasional Institut of Islam Thought And Civilization (ISTAC) malaysia. Hasil penelitian menunjukkan bahwa konsep adab Alatas berbeda dengan konsep ada para ulama sebelumnya termasuk dengan al-Ghozali yang banyak memberi pengaruh dalam pemikirannya. Ubaidillah Al Ghifary Slamet (2016) juga telah mengangkat penelitian tentang konsep pendidikan akhlak Al Khatib Al-Baghdadi dalam Kitab Al-Jami Li Akhlaqi Al-Rawi Wa Adab Al-Sami' dan Al-Faqih Wa Al-Mutafaqqih". Terakhir, Dahlan (2015) dalam penelitiannya juga mengangkat konsep pendidikan karakter Thomas Lickona dan pendidikan akhlak Ibn Miskawih serta implementasinya di Sekolah Menengah Pertama Negeri 49 Jakarta.

Walaupun memiliki keidentikan yang sama dari segi tema dan judul terkait dengan adab hiwar (etika berdialog), namun terdapat beberapa hal yang berbeda. Dalam penelitian ini, pemikiran Muhammad Sayyid Thanthawi yang menjadi sorot utama 
adalah tentang adab hiwar yang dikolaborasikan dengan pembelajaran aktif dalam kurikulum 2013, ranahnya tidak sekedar berkutat pada etika dalam proses pembelajaran saja, namun lebih spesifik mendiskripsikan adab berdialog dalam Islam, utamanya saat melakukan diskusi pada pembelajaran aktif. Penelitian ini kemudian berupaya menalaah signifikasi dan mengungkap sejauh mana relevansinya dengan program pendidikan di Indonesia serta menemukan relevansi dan aplikasinya dalam pembelajaran siswa aktif tersebut secara strategis-konsepsional.

\section{Metode Penelitian}

Dari tema sentral dan deskripsi objek kajiannya, peneliti ini merupakan jenis penelitian literatur atau kepustakaan (Library Research) karena dilakukan di perpustakaan dengan tujuan untuk menganalisis isi buku (content analysis) (Arikunto, 2010) yang menggunakan kitab utama Adab Hiwar fi al-Islam karya Muhammad Sayyid Thanthawi. Penelitian ini juga dikategorikan sebagai kualitatif yang menekankan setiap temuan (sementara) dilandaskan pada data (Gall dan Borg, 2003; Moleong, 2013), sehingga temuan ini semakin tersahihkan sebelum dinobatkan sebagai teori Alwasilah (2012) bertujuan untuk mendeskripsikan keutuhan gejala atau peristiwa dengan memahami makna dari segala peristiwa tersebut.

Penelitian ini juga berusaha untuk mencari sumber data sekunder lain yang mendukung penelitian, serta untuk mengetahui sampai kemana ilmu yang berhubungan dengan penelitian telah berkembang, sampai kemana terdapat kesimpulan dan degeneralisasi yang pernah dibuat, sehingga situasi yang diperoleh oleh Nazir (2011) sesuai dengan locus dan tempus penelitian, spesifiknya yang terkait dengan adab hiwar dalam konteks pembelajaran aktif pada kurikulum 2013. Sumber data premier ${ }^{1}$ dalam penelitian ini adalah kitab Adab Hiwar fi al-Islam karya Muhammad Sayyid Thanthawi yang mendeskripsikan dengan jelas pandangannya mengenai adab berdialog secara islami (Maqbul, 2008; Al-'Uwaidah, 1992).

Dalam penelitian ini, dari empat cetakan kitab, sumber premier yang dijadikan sebagai referensi utama yang banyak digunakan untuk mengelaborasi pemikiran Muhammad Sayyid Thanthawi adalah kitab Adab Hiwar fi al-Islam, karena memiliki keunggulan dalam gaya penulisan yang rapi dan jelas serta banyak memberikan banyak komentar disertai interpretasi al-Qur'an yang luas dari berbagai penafsir sehingga mampu memberikan informasi yang absah mengenai topik terkait, tanpa terselingi dan terselipi oleh penjelasan lain yang bukan merupakan tema pemikirannya. Sedangkan sumber data sekunder yang digunakan adalah karya ilmiah, buku-buku dan tulisan

\footnotetext{
${ }^{1}$ Dalam perspektif para pakar Muslim dalam diskursus metodologi penelitian (bahst ilmi) dan akurasi naskah (tahqiq alturats), sumber data premier dinyatakan sebagai sumber otentik (mashadir) yang harus dijadikan sebagai sumber utama (ashaliyyah), sedangkan sumber data sekunder dikategorikan sebagai referensi (maraji') atau sumber nukilan (naqilah),
} 
karya-karya para ulama dan pakar pendidikan lain yang megelaborasi pemikiran pendidikan Muhammad Sayyid Thanthawi yang terkait dengan judul dan tema sejenis serta buku-buku yang berkaitan dengan teori Pembelajaran Aktif, khususnya tentang konsep adab berdialog, dan pembelajaran siswa aktif pada kurikulum 2013, serta tentang konsep dan aplikasi yang diusung dalam pembentukan model pembelajaran aktif.

Teknik analisis data yang digunakan dalam penelitian ini adalah metode analisis isi (content analysis) karena berkaitan dengan isi pesan yang terkandung dalam karya Muhamad Sayyid Thanthawi yang memang harus dianalisis secara ilmiah, metodologis dan kritis. Analisis isi adalah teknik penelitian untuk membuat inferensi-inferensi (proses penarikan kesimpulan berdasarkan pertimbangan yang dibuat sebelumnya atau pertimbangan umum; simpulan) yang dapat ditiru (replicabel) dan sahih data dengan memperhatikan konteksnya (Bungin, 2003).

Selanjutnya, untuk mengakurasi data penulis menggunakan metode dokumentasi ${ }^{2}$ yang dilakukan di ruang-ruang perpustakaan, baik pustaka pribadi, perpustakaan kampus, perpustakaan umum maupun melalui pencarian di internet (Arikunto, 2010; Sugiyono, 2012). Kemudian, hasil dokumentasi tersebut dicatat dalam komputer sebagai alat bantu pengumpulan data sebelum dilakukan analisa dan disimpulkan konsepsi yang menjadi karakteristik pemikiran para tokoh yang menjadi objek penelitian, yaitu Muhammad Sayyid Thanthawi dalam kitab 'etika berdalog' tersebut, khususnya yang mengelaborasi tentang adab hiwar dalam Islam.

Selanjutnya, Metode yang digunakan dalam penelitian ini adalah naturalistic inquiry. Merriam (1998) menjelaskan bahwa naturalistic inquary hanyalah istilah lain yang sering digunakan untuk penelitian kualitatif, atau Agostinho (2005) yang menjelaskan bahwa naturalistic inquiry adalah paradigma yang dibangun untuk penelitian kualitatif. Namun, beberapa penulis menyebutnya sebagai salah satu jenis penelitian kualiatatif.

\section{Hasil dan Pembahasan}

\section{A. Adab Berdialog}

Secara literal-etimologis berdasarkan aspek linguistiknya al-adab dengan bentuk plural (jamak)nya al-adab memiliki arti al-du'a (Al-Misri, 2009; Humaid, et al, 2013) yang berarti undangan seruan atau panggilan dan juga berarti al-zaraf wa husn al-tanawul, yaitu suatu bentuk kesopanan dan etika berinteraksi yang baik dengan orang lain

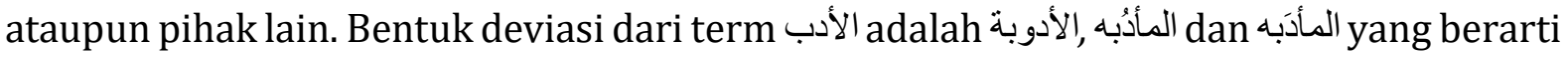

\footnotetext{
${ }^{2}$ Yaitu mencari data mengenai hal-hal atau variabel yang berupa catatan, transkrip, buku, surat kabar, majalah, prasasti, notulen rapat, lengger, agenda, dan sebagainya. Bila diklarifikasikan lebih lanjut, dokumen tersebut bisa berbentuk tulisan, gambar, atau karya-karya menumental dari seseorang. Dokumen yang berbentuk tulisan misalnya catatan harian, sejarah kehidupan (Life histories), cerita, biografi, peaturan, kebijakan,. Dokumen yang berbentuk gambar, misalnya foto, gambar hidup, sketsa dan lain-lain. Dokumen yang berbentuk karya misalnyakatya seni, yang dapat berupa gambar, patung, film, dan lain-lain.
} 
yaitu makanan atau jamuan makan yang secara khusus dihidangkan dalam rangka mengundang orang lain untuk menikmatinya atau dapat juga berarti:

$$
\text { كل طعام صنع لدعوة مأدبة"، والصلة بين المأدبة والوليمة أن الوليمة أخص من المأدبة }
$$

"Yaitu setiap hidangan makanan yang dipersiapkan untuk undangan perjamuan dan pesta pernikahan atau kenduri."

Penegasan kalimat المأدبَه dalam hadis yang diriwayatkan Ibnu Mas'ud:

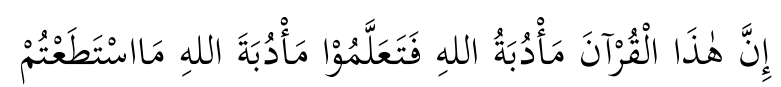

"Sesungguhnya Al-Qur'an ini sebagai hidangan (jamuan) Allah, maka pelajarilah hidangan Allah itu sedapat-dapatnya". (HR. Addarimi)3.

Ketika Al-Qur'an suci itu sendiri digambarkan sebagai undangan Tuhan untuk menghadiri suatu perjamuan diatas bumi, dan kita sangat dianjurkan untuk mengambil bagian didalamnya dengan jalan pengetahuan yang benar tentangnya (Al-Attas, 1979). Dari definisi-definisi tersebut dapat disimpulkan bahwa dalam tataran etimologis adab belum terkait secara eksplisit dengan pendidikan suatu keterampilan atau disiplin ilmu tertentu kecuali secara praksis terkait dengan etika kesopanan dan itupun dalam lingkup yang masih sempit yaitu etika di meja makan atau kesopanan dalam memenuhi undangan dan jamuan makan.

Dari paparan tentang definisi adab secara terminologis dapat diidentifikasikan bahwa $a d a b$ dapat dimaknai sebagai budi pekerti yang baik, perilaku yang terpuji, jiwa dan akhlak yang terdidik, kedisiplinan untuk menjadi orang yang beradab, moral atau moralitas afeksi Susila tapi ada nilai etika dan karakter secara teknis praktis dapat pula dimaknai sebagai tata krama dan sopan santun. ${ }^{4}$ karena ada merujuk pada pengenalan dan pengakuan atas tempat kedudukan dan keadaan yang tepat dan benar dalam kehidupan dan untuk disiplin Sebagai pribadi ikut serta secara positif dan rela memainkan peran seseorang sesuai dengan pengenalan dan pengakuan tersebut (AlAttas, 1981)

Al-Hiwar (الحوار) secara etimologi berasal dari kata kerja (الحار) yang berarti (رجع) yaitu, "kembali" (Ibn Mandhur, 1988; Az Zubaidi, 1994) dalam keterangan yang lain mengertikan "jawaban" (الردّ), dan berarti "tanya jawab", "percakapan", "dialog”, (المحاورة) (Ma'luf, 1986; Munawwir, 2007). Makna-makna yang terakhir inilah yang sering

\footnotetext{
${ }^{3}$ Atsar ini diriwayatkan oleh Darimi (II/525) no. 3323 dengan sanad shahih dari Ibnu Mas'ud yang diringkas.
} 
digunakan bagi nama suatu model pengajaran. Di dalam al-Qur'an terdapat tiga ayat yang menggunakan kata (المحاورة) yaitu pada surat al-Kahfi ayat 34 dan 37, surat al-Mujadalah ayat pertama (Kesuma, 2011; Sauri, 2011). Dua ayat yang terdapat pada surat al-Kahfi, mengenai dialog seorang pemilik kebun dengan seorang sahabatnya yang tidak memiliki banyak kekayaan seperti pemilik kebun, yaitu :

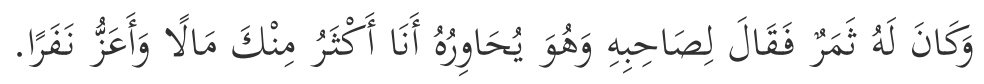

"Dan dia mempunyai kekayaan besar, maka ia berkata kepada kawannya (yang mukmin) ketika bercakap-cakap dengan dia: "Hartaku lebih banyak dari pada hartamu dan pengikut-pengikutku lebih kuat". (QS.al-Kahfi:34)

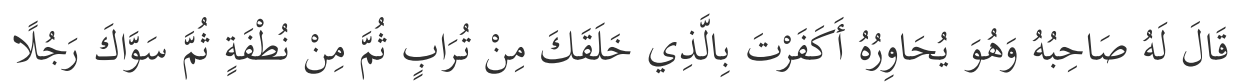

"Kawannya (yang mukmin) berkata kepadanya -- sedang dia bercakap-cakap dengannya: "Apakah kamu kafir kepada (Tuhan) yang menciptakan kamu dari tanah, kemudian dari setetes air mani, lalu Dia menjadikan kamu seorang laki-laki yang sempurna?". (QS.al-Kahfi:37)

Dialog, yang dalam bahasa Arab tadi disebut Hiwar, sebenarnya sudah lama dipakai orang semenjak zaman Yunani (Departemen Bahasa Arab, 2005). Ahli-ahli pendidikan Islam telah mengenal istilah ini, yang dianggap oleh pendidik-pendidik modern berasal dari Filosof Yunani Socrates, Ia memakai metode ini untuk mengajar muridnya supaya sampai ketaraf kebenaran sesudah bersoal jawab dan bertukar fikiran (Ramayulis, 2006).

Sedangkan Metode Hiwar yang digali dari sumber Islam, yaitu al-Qur'an dan Hadis, sudah tentu dapat dipakai dalam pendidikan Islam, sesuai dengan tujuan pengajaran yang hendak dicapai. Bisa jadi metode ini dapat menambah metode-metode dari Barat. Yang jelas, ada beberapa tujuan pendidikan dalam Islam yang tidak dapat dicapai hanya dengan menggunakan metode mengajar dari Barat. Metode dari al- Qur'an dan Hadis ini, mungkin dapat menutup kekurangan itu (Tafsir, 1991; Hefni, 2015).

\section{B. Pembelajaran Aktif}

\footnotetext{
${ }^{5}$ hiwar dalam kamus Mu'jam yaitu: حديثُ يجري بين شخصين او أكثر في العمل القصصيّ. او بين ممثلين او أكثر علي المسرح "Dialog yang terjadi antara dua orang atau lebih dalam aktivitas pengkisahan, atau antara dua aktor atau lebih diatas pentas/panggung”.
} 


\section{Maulana, Nata \& Bahruddin}

Belajar aktif merupakan sebuah model pembelajaran yang memberi peluang sangat luas bagi peserta didik untuk belajar lebih mandiri, dalam hal ini juga mengurangi porsi pendidik untuk berceramah dengan memperbanyak penugasan pada peserta didik melalui diskusi tugas dan lain sebagainya. Active learning (belajar aktif) juga dapat diartikan sebagai belajar yang memperbanyak aktivtas peserta didik dalam mengakses bergabagai informasi dari berbagai sumber. Misalnya lewat buku teks, perpustakaan, internet, majalah, koran, atau sumber-sumber belajar lainnya yang mampu menunjang pengetahuan belajar peserta didik. Selanjutnya informasi yang telah diperoleh dari berbagai sumber tersebut dibahas dalam proses pembelajaran dalam kelas. Sehingga peserta didik memperoleh berbagai pengalaman yang tidak saja menambah kompetensi pengetahuan mereka, tetapi juga kemampuan analitis, sintesis, dan menilai informasi yang relevan untuk dijadikan bagian dari nilai yang diadopsi dalam hidup mereka, diimitasi, dibiasakan sampai mereka adaptasikan dalam kehidupan (Rosyada, 2004).

Sebagai konsep, active learning adalah suatu proses kegiatan belajar mengajar yang subyek didiknya terlibat secara intelektual dan emosional sehingga ia betul-betul berperan dan berpartisipasi aktif dalam melakukan kegiatan belajar (Rosyada, 2004). Pengertian tersebut menunjukkan bahwa belajar aktif menempatkan siswa sebagai inti dalam kegiatan belajar mengajar siswa dipandang sebagai objek dan subjek didik.

Dilihat dari subyek didik, active learning merupakan proses kegiatan yang dilakukan oleh siswa dalam rangka belajar. Dilihat dari segi guru atau pengajar, Active learning merupakan bagian strategi mengajar yang menuntut keaktifan optimal subyek didik. Bertitik tolak dari uraian di atas, maka dapat diambil kesimpulan bahwa yang dimaksud dengan active learning adalah salah satu cara strategi belajar mengajar yang menuntut keaktifan dan partisipasi subyek didik seoptimal mungkin sehingga siswa mampu mengubah tingkah lakunya secara lebih efektif dan efisien (Rosyada, 2004).

Menurut ALIS (Active Learning In School) pembelajaran aktif yang dilaksanakan di sekolah-sekolah pada hakikatnya sama dengan CBSA (Cara Belajar Siswa Aktif), Prinsipprinsip pembelajran aktifnya sebagai berikut (Amri, 2015):

1. Prinsip melakukan (to do), yang dalam CBSA disebut belajar sambil bekerja pada dasarnya pembelajaran itu harus membuat peserta didik berbuat sesuatu, bukan tinggal diam, berpangku tangan. Perbuatan itu dapat berupa; melihat, mendengar, meraba, merasakan, menulis, mengukur, membaca, menggambar, menghitung yang pada dasarnya sama dengan keterampilan proses.

2. Prinsip menggunakan semua alat indera (pancaindera), bahwa dalam pembelajaran hendaknya mengaktifkan semua alat indera untuk memperoleh informasi atau pengetahuan (to know), melalui melihat, mendengar, meraba, mengecap, dan membau. Dengan mengerahkan seluruh indera(sejauh memungkinkan) peserta didik akan 
memperoleh pengetahuan atau informasi yang lebih mengesankan, bukan sekedar hafalan, dan tidak mudah dilupakan.

3. Prinsip eksploirasi lingkungan (to life together), bahwa pembelajaran aktif memanfaatkan lingkungan sebagai sarana, media, atau sumber belajar. Lingkungan itu dapat berupa lingkungan fisik, lingkungan sosial, lingkungan budaya, dan juga lingkungan mental. Lingkungan itu dapat berupa objek (benda-benda), tempat (situasi dan kondisi), kejadian atau peristiwadan ide atau gagasan.

\section{Kaidah Adab Berdialog dalam Kitab Adab Hiwar Fi Al-Islam}

Berbagai perbedaan antara manusia lebih banyak disebabkan mengenai masalah agama dan dunia, selanjutnya, dalam kitab Adab Hiwar Fi Al-Islam dikatakan bahwa syariat islam dikonstruksikan dari sebuah prinsip yang luhur, etika yang tinggi, dan petunjuk yang agung. Sehingga apapun yang ditetapkan menegenai perbedaan, dialogdialog dan pendapat-pendapat yang berlaku diantara manusia, menjadikan sirkulasi yang berkembang tersebut akan berasal dari logika yang selamat. Pemikiran yang terstruktur, dan perdebatan yang baik. Sehingga hal tersebut mengarah pada tujuan kebenaran, kebaikan dan bermanfaat atas batasan-batasan yang telah Allah halalkan.

Imam Sayyid Thanthawi mendeskripsikan dialog dalam Islam pada sebelas prinsip utama (indikator) yang terkait dengan $a d a b$ berdialog secara Islami, yaitu diantarnya adalah pertama, hendaknya dialog yang dikembangkan dibangun atas dasar kejujuran, jauh dari dusta, menyesatkan, dan ilusi. Al-Qur'an telah meletakkan dasar atas berbagai macam dialog yang terjadi antara rasul dan kaumnya, orang-orang membangun dan orang-orang yang merusak. Memberikan mereka sudut pandang yang dikonstruksikan atas dasar kebenaran dari yang difikirkan oleh para pendusta, dan mengarahkan kebenaran dari stagnasi kebathilan. Hal ini dapat terlihat bagaimana saat nabi Musa menyanggah Fir'aun, dimana akan didapati bahwa kejujuran nabi Musa dapat memusnahkan kebohongan, dan kejujuran ini lahir dari bersihnya hati, yang jauh dari kebencian dan kedengkian, berasal dari hati yang jernih tanpa mengenal kepicikan atau kecurangan, bersumber dari akal sehat yang diberikan Allah sebagai penguat untuk menunjukkan kecerdasan, kepintaran dan kebijakan seorang nabi dalam menghadapau kebatilan melawan Fir'an yang diliputi dengan dugaan yang penuh dengan kebohongan. Kedua, Hadirnya adab dalam syariat Islam adalah untuk menata perbedaan dan percakapan yang terjadi diantara manusia, hingga jelaslah tujuannya, hingga pada hasil yang memuaskan, sesuai dengan tema yang berlaku (tidak keluar dari topik pembicaraan) yang dapat memicu kesalahpahaman(fokus), sehingga pelbagai permasalah yang terjadi dapat di musyawarahkan dengan topik tertentu. Dewasa ini kita biasa menyebutnya dengan istilah kolaborasi, disaat para pemikir belum menyadari asal perbedaan yang terjadi, mengenal perbedaan yang menyabang hingga tidak ketemu 
ujung pangkalnya. Dalam al-Qu'ran, maka akan ditemui banyak sekali perdebatan, perbincangan, dan perbedaan pendapat yang terjadi antara seorang Rasul dan kaumnya yang dahulu telah ditemukan akar permasalahan yang terjadi antara mereka, seperti misalnya yang tercerminkan dari kisah Nabi Nuh dalam menghadapi kaumnya saat menolak dakwahnya.

Ketiga, hadirnya syariat islam juga dapat menghapus berbagai macam perbedaan yang terjadi: mengahadirkan dalil yang autentik, bukti yang akurat dan logika yang sehat, baik dihadapan orang-orang yang menyombongkan diri ataupun orang-orang yang bengis, hingga menjadikan mereka terdiam dalam perdebatan. Hal ini tercerminkan dalam al-Qur'an seperti kisah nabi Ibrahim yang memberikan sanggahan di hadapan raja kafir yang dzalim. Keempat, diantara prinsip syariat Islam dalam menyikapi perbedaan yang terjadi di kalangan masyarakat: hendaknya masing-masing kubu yang berselisih mampu mampu memperjelas letak perbedaan secara realistik dan benar sesuai topik pembahasan. Hingga tampaklah kejelasan duduk perkaranya. Seperti perbedaan pendapat yang terjadi antara Umar bin Khottob dan Abu Bakar ash-Shiddiq mengenai masalah pengumpulan al-Qur'an sepeninggalan Nabi SAW. Pada awalnya Abu Bakar enggan menyikapi masalah tersebut, namun setelah Umar menyampaikan pendapatnya, pada akhirnya Abu Bakar menyetujui hal tersebut.

Kelima, diantara tujuan dicantumkannya adab berdialog dan berdiskusi dalam syariat Islam adalah: disampaikan dengan ketawadhu'an (kerendahan hati), menghidari egoisme, menggunakan etika kesantunan, bersih dari hal-hal yang dipandang tidak layak untuk diperbuat. Indikator ini terdapat pula dalam kisah Nabi Sulaiman yang telah Allah anugrahkan kerajaan yang tiada seorangpun dapat menandingi kerajaan beliau setelahnya. Saat beliau memeriksa pasukannya, tidak ditemukan kehadiran burung hudhud diantara mereka, hingga akhirnya datanglah burung hud-hud kepadanya sembari mengatakan dengan segenap keberanian yang ia miliki, dan nabi Sulaiman pun menerima argumen burung Hud-hud dengan penuh ketawadhu'an. Keenam, undang-undang yang telah ditetapkan syariat Islam dalam bedialog sebenarnya telah ada ditengah masyarakat seperti misalnya memperluas ruang publik dalam berdiskusi dan dalam beroposisi agar publik mampu melihatnya dengan jelas sehingga tidak banyak opsi yang berkembang ataupun hanya mengarah pada kepentingan pribadi.

Ketujuh, beberapa hal yang dapat dikategorikan etika berdialog dalam Islam diantaranya adalah menghormati pendapat dan gagasan para pakar ahli, yang berlogika dengan kalimat yang santun, yang beragumen meyakinkan, yang perbuatannya diiringi perilaku terpuji, memaafkan secara santun segala hal yang dipandang tidak bermanfaat. Hal ini tampak dari cara mereka mengembangkan wawasan mereka, menyucikan jiwa, hati, asa, dan mental mereka. Kedelapan, etika yang ada di dalam Islam yaitu tidak menjeneralisir didalam menentukkan hukum, menjaga tutur kata, membatasi permasalahan dengan ketentuan batas yang mendalam, meletakkan kalimat-kalimat 
pada topik yang tepat, memutuskan perkara dengan menimbang bibit dan bobotnya, jujur dan adil, seimbang dalam menimbang perbuatan sehingga tidak mendzalimi orangorang bertaqwa, terhormat, dan istiqomah, tidak tunduk pada orang-orang yang menuruti hawa nafsunya, dan tidaklah buta dan tuli dalam menegakkan kebenaran. Kesembilan, diantara hal yang perlu dilakukan agar dialog dapat menjadi sebuah perbincangan yang berfedah dan bermanfaat adalah dengan mengkaji hasil-hasil dan menimbang baik buruknya pembicaraan: hendaknya dikonstruksikan dengan data dilapangan yang lebih akurat, bukan berdasarkan asumsi-asumsi yang penuh dengan kebohongan, dan mengkostruksikannya dengan informasi yang valid bukan hoks.

Sepuluh, dialog yang dibangun atas kebenaran yang kuat, informasi yang akurat dan berita yang valid akan melahirkan keberkahan dari Allah, memperkokoh rasa gotongroyong atas paying kebaikan dan ketaqwaan serta menjauhkan diri dari perbuatan dosa dan permusuhan. Sedangkan dialog yang dibangun atas hoaks, data yang batil dan presepsi negative hanya akan menghasilkan kehancuran dan kerugian karena pada dasarnya ketetapan yang tidak vaild akan dimenangkan oleh kevalidan, dan sunatullah tidak akan pernah terganti. Dan sebelas, diantara adab berdialog yang lainnya: komunikasi dilakukan secara terbuka dan apa adanya, dengan mengedepankan kebenaran yang disertai dengan bukti dan dalil yang valid sehingga diharapkan dapat diterima akal sehat dan mendalam bagi undang-undang dan hukum syariat.

\section{Implementasi Adab Berdialog menurut Muhammad Sayyid Thanthawi dalam Pembelajaran Aktif di Sekolah}

Secara umum, untuk menerapkan indikator dialog dan pembelajaran siswa aktif diatas, digunakan model atau alur sebagai berikut:

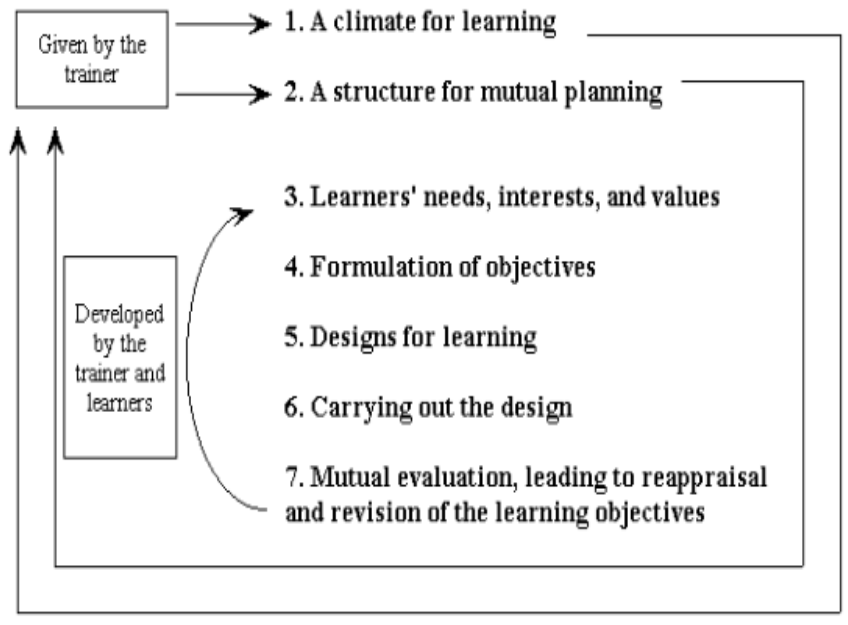

Sumber: Laird, 1985

Gambar 1: Model Umum Penerapan Pembelajaran Aktif (Laird, 1985) 
Terkait dengan upaya mengimplementasikan konsep di atas, L. Dee Fink menyampaikan 3 (tiga) saran, sebagai berikut: Pertama, memperluas jenis pengalaman belajar. Dalam hal ini, pendidik (guru) dapat membuat kelompok-kelompok kecil siswa dan meminta mereka membuat keputusan atau menjawab sebuah pertanyaan terfokus secara berkala. Guru juga dapat menemukan cara agar siswa dapat terlibat dalam berbagai dialog otentik dengan orang lain, di luar teman-teman sekelasnya (di website, melalui email, atau dalam kehidupan nyata). Saran lainnya adalah mengambil manfaat dari "Power of Interaction." Dari keempat bentuk belajar di atas, masing-masing memiliki nilai tersendiri, tetapi apabila keempat bentuk belajar tersebut (Dialogue with Self, Dialogue with Others, Observing, dan Doing) dikombinasikan secara tepat, maka akan dapat memberikan efek belajar yang lebih kaya kepada para siswa. Para pendukung Problem-Based Learning menyarankan kepada para guru untuk mengawalinya dengan kegiatan "Doing", dimana guru terlebih dahulu mengajukan berbagai masalah nyata (real problem) untuk diselesaikan oleh siswanya. Kemudian, siswa diminta untuk berkomunikasi dan berkonsultasi dengan rekan-rekan sekelompoknya (Dialogue with Others) untuk menemukan cara-cara terbaik guna memecahkan masalah nyata yang telah diajukan. Setelah para siswa saling berkomunikasi dan berkonsultasi, selanjutnya para siswa akan melakukan berbagai macam bentuk belajar sesuai pilihannya, termasuk didalamnya melakukan Dialogue with Self dan Observing.

Saran terakhir adalah dengan membuat dialektika antara pengalaman dan dialog. Melalui pengalaman (baik melalui doing dan observing) siswa memperoleh perspektif baru tentang apa yang benar (keyakinan) dan apa yang baik (nilai). Sementara melalui dialog dapat membantu siswa untuk mengkonstruksi berbagai makna dan pemahamannya. Untuk menyempurnakan prinsip interaksi sebagaimana dijelaskan di atas yaitu dengan melakukan dialektika antara kedua komponen tersebut. Dalam hal ini, secara kreatif guru dapat mengkonfigurasi dialektika antara pengalaman baru yang kaya dan mendalam dengan dialog yang bermakna, sehingga pada akhirnya siswa benar-benar dapat memperoleh pengalaman belajar yang signifikan dan bermakna.

Dalam setiap pelaksanaan pembelajaran aktif di Sekolah, seorang pendidik hendaknya mempertimbangkan pelbagai faktor. Selain karena pembelajaran itu pada dasarnya merupakan implementasi dari kurikulum yang berlaku, juga senantiasa membutuhkan landasan-landasan yang kuat dan dimuarakan atas hasil-hasil pemikiran yang mendalam. Pembelajaran aktif dialogis memiliki posisi dan potensi yang sangat strategis dalam keberhasilan proses belajar dan pembelajaran. Dengan posisi itu, maka dalam pembelajaran aktif dialogis dibutuhkan berbagai landasan yang kokoh dan kuat serta perlu memperhatikan agenda pembelajaran yang mencakup rencana, pelaksanaan, dan penilaian proses berikut hasilnya. Landasan-landasan pembelajaran aktif meliputi dua hal yaitu: Pertama, Landasan Yuridis, Kedua, Landasan Filosofi. Landasan Yuridis 
berkaitan dengan kebijakan atau peraturan yang mendukung pelaksanaan pembelajaran aktif dialogis di Sekolah sedangkan landasan filosofis yaitu meliputi (1) Konstruktivisme, (2) Behavioriesme, (3) Naturalistik yang memandang proses pembelajaran perlu ditekankan pada pembentukan berfikir ilmiah, pengalaman belajar dan memperhatikan suasana alamiah (natural) siswa sebagai centre learning.

Ada muatan penguasaan dalam interaksi yang membuat setiap diri pada akhirnya mengambil hikmah pembelajaran dari proses yang dilalui. Kirshner dan Whitson (1997), menguraikan bahwa ada satu kondisi yang mempengaruhi proses kemampuan pemahaman belajar yang disebutnya dengan situativity theory dimana situasi belajar yang memiliki vitalitas yang sangat berperan menciptakan 'ekologi' dalam proses belajar dan ilmu pengetahuan diberbagai hal (Sulastini, 2018). Disinilah L Dee Fink berusaha untuk mengkonstruksikan pembelajaran dinamis Berdasarkan 6 Significant Learning yait (Sulastini, 2018): (1) Dimensi Pengetahuan Dasar: yang meliputi memahami dan mengingat.; (2) Dimensi Penerapan: Berpikir kritis, kreatif dan praktis; memecahkan masalah. (3) Dimensi Penyatuan: menghubungkan antar ide, gagasan, subyek dan orang; (4) Dimensi Kemanusiaan: belajar tentang dan perubahan diri seseorang, memahami dan berinteraksi (5) Dimensi Kasih sayang: (6) Dimensi Belajar untuk belajar.

Ke-enam konsep diatas perlu diselaraskan dengan 11 kaidah adab berdialog Imam Thanthawi untuk menemukan sisi-sisi yang perlu dilengkapi untuk meletakkan kaidah dasar pembelajaran aktif dialogis dalam perspektif islam secara strategis, kemudian menemukan padanan yang belum dapat terinternalisasi pada taksonomi fink diatas.

1. Dimensi Pengetahuan Dasar: yang meliputi memahami dan mengingat pada dimensi ini mencakup kaidah ke- ke-7 dari adab berdialog yang telah terintegrasi dengan pembelajaran aktif yaitu: (7) berdialog diperlukan akurasi pendapat yang mumpuni sehingga mengutamakan pendapat para pakar yang ahli dibidangnya, akurasi ini akan menjadi pengetahuan dasar yang kuat bagi peserta didik dalam proses memahami dan mengingat pelajaran.

2. Dimensi Penerapan: Berpikir kritis, kreatif dan praktis, pada dimensi ini senada dengan kaidah adab berdialog yang ke-4 dan ke-8 yaitu: (4) berdialog hendaknya memperjelas letak perbedaan secara konkrit dan benar sesuai pembahasan. Seseorang yang berfikir kritis akan mampu berfikir secara kritis hingga dapat menyelesaikan setiap permasalahannya secara kreatif dan menemukan titik permasalahan secara konkrit sehingga peserta didik mampu menemukan solusi yang tepat dalam menghadapi setiap permasalahannya bukan hanya di sekolah namun lebih jauh lagi yaitu kehidupan yang dilalui peserta didik. (8) dialog yang baik adalah dialog yang pada pengejawentahannya tidak menjeneralisir hukum. Pada segmen ini pengelompokan jenis hukum yang berlaku akan melatih seseorang 
untuk berfikir sitematis yang akhirnya dari kesistematisan tersebut akan muncul sikap kritis dan kreatif.

3. Dimensi Penyatuan: menghubungkan antar ide, gagasan, subyek dan orang. Dimensi ini pada tatanan adab berdialog memasuki dua ranah sekaligus yaitu: kaidah ke-2 dan kaidah ke-5 yaitu: (2) Dialog yang baik hendaknya berfokus pada topik pembahasan. Topik pembahasan ini menjadi objek pendidikannya dan siswa sebagai subjeknya. Kedua item ini haruslah diperhatikan oleh pendidik agar dapat menentukan arah yang jelas pada proses pembelajarannya (5) hendaknya dalam berdialog etika kesantunan dikedepankan demi menghindari perbuatan yang tidak layak. Kelayakan dalam menyatukan ide gagasan seyogyanya dipadukan secara utuh sehingga tidak menjadi pembalajaran yang sifatnya parsial. Ibarat sebuah puzzle semua hal yang dapat dihubungkan dalam dimensi pembelajaran hendaknya dikaitkan secara utuh dalam al-Qur'an biasanya digunakan kalimat 'udkhulu fi silmi kafah' (QS.al-Baqarah:208) yang artinya kurang lebih 'Masuklah kalian ke dalam Islam secara totality'.

4. Dimensi Kemanusiaan: belajar tentang dan perubahan diri seseorang, memahami dan berinteraksi. Dimensi ini memasuki kaidah yang ke-5 yakni: berdialog mengarah pada kepentingan umum dan general. Seseorang yang berinteraksi sosial akan mengedepankan kepentingan umum dan menyisihkan kepentingan pribadi. Kebersamaan dan kerja sama sangat diperlukan dalam pembelajaran untuk menciptakan iklim belajar yang kondusif dan efisien. Hal ini juga tercantum dalam pancasila sila ke-2 yaitu kemanusiaan yang adil dan beradab. Manusia yang adil dalam arti tidak dzalim adalah manusia yang mampu memanusiakan manusia dengan etika yang baik.

5. Dimensi Kasih sayang, mengidentifikasi/perubahan perasaan. Pada segmen ini hal yang seanada diungkapkan pada kaidah ke-9 yaitu: berdialog hendaknya sedapat mungkin meninjau ulang dasar kemanfaatan dan madharatnya dalam berdialog. Kaidah menunjukkan bentuk kasih sayang dan empati seorang muslim dalam menghadapi orang yang belum faham akan keilmuan (baca:bodoh), sehingga Allah memerintahkan untuk memaafkan kebodohan orang yang belum mengerti dengan tetap mengerjakannya kebaikan tanpa putus asa.

6. Dimensi Belajar untuk belajar: belajar. Kata kerjanya mengkritisi dan menganalisis. Pada taraf yang ke enam ini kaidah adab berdialog dapat terintegrasi pada 3 kaidah sekaligus diantaranya: kaidah ke-1, 10 dan 11. kaidah (1) konstruk dialog berasal dari kejujuran. Jika sesorang berniat belajar untuk belajar. Maka ia harus menanyakan kepada dirinya terlebih dahulu, apakah ia termasuk kategori pembelajar yang berorientasi pada entitas (yang mengedepankan gaya dan ingin terlihat pandai), ataukah ia kategori pemelajar inkrimental (yang belajar karena memang ingin tahu) (Dwek, 2020); (10) Pendialog hendaknya mengupgrade 
pemahaman dan mengakurasikan hukum yang telah disepakati oleh para ahli. Jika seorang pmebelajar sejati ia akan berusaha semaksimal mungkin untuk terus mendinamiskan pembelajarannya secara aktif . tidak merasa cukup dengan hal yang sudah dipahaminya, namun terus mengeksplor pemahamannya (11) dialog yang beradab seyogyanya bersifat transparan dan apa adanya. Pada segmen ini belajar untuk belajar tidak usah ditutupi dengan perasaan gengsi, jika tidak tahu maka penting untuk mengakui bahwa dirinya tidak tahu, tidak mentup diri sehingga malu untuk belajar. Atau sebaliknya terlalu confident hingga meremehkan orang lain, dan tidak mau belajar dari pengalaman-pengalaman yang dialami, sehingga seseorang pada segmen ini akan merasa dirinya cukup pandai dan berhenti untuk belajar.

Setelah mendalam ke-enam item taksonomi Fink, penelitian ini menemukan satu kaidah yang belum dapat terinternalisasi dalam taksonomi Fink, kaidah itu adalah kaidah dialog yang ke-3 yaitu: berdialog hendaknya mampu menghadirkan dalil akurat dan logika sehat. Kaidah ini terlihat sederhana namun, penulis rasa ini penting, kerena menghadirkan dalil yang akurat dibutuhkan sumber baca yang valid. megeksplor sumber baca yang akurat akan menajamkan proses belajar seseorang, karena apa yang dipelajari memiliki tingkat akurasi keilmuan yang dapat dipertanggung jawabkan, sedangkan seseorang tanpa sumber data yang valid dalam sains ilmiah dapat dikatakan hoaks, dalam Islam sumber baca ini telah disinggung pada permulaan turunnya al-Qur'an yang familiar disebut dengan istilah 'iqra' (bacalah) merupakan tonggak utama yang menjadi landasan filosofi bagi seluruh umat islam dan terbukti ilmiah. Membaca menjadi sangat penting karena membaca adalah suatu proses yang dilakukan untuk memperoleh pesan atau informasi.

7. Dimensi membaca, Kridalaksana (1985) mengemukakan bahwa dalam kegiatan membaca melibatkan dua hal (Dalman 2018), yaitu pembaca yang berimplikasi adanya pemahaman dan (2) teks yang berimplikasi adanya penulis. Syafi'ie (1999) menyebutkan hakikat membaca adalah pengembangan keterampilan, mulai dari keterampilan memahami kata-kata, kalimat-kalimat, paragraf-paragraf dalam bacaan sampai dengan memahami secara kritis dan evaluatif keseluruhan isi bacaan. Kegiatan visual, berupa serangkaian gerakan mata dalam mengikuti barisbaris tulisan, pemusatan penglihatan pada kata dan kelompok kata, melihat ulang kata dan kelompok kata untuk memperoleh pemahaman terhadap bacaan. Kegiatan mengamati dan memahami kata-kata yang tertulis dan memberikan. makna terhadap kata-kata tersebut berdasarkan pengetahuan dan pengalaman yang telah dipunyai. Suatu proses berpikir yang terjadi melalui proses mempersepsi dan memahami informasi serta memberikan makna terhadap bacaan.Proses mengolah 


\section{Maulana, Nata \& Bahruddin}

informasi oleh pembaca dengan menggunakan informasi dalam bacaan dan pengetahuan serta pengalaman yang telah dipunyai sebelumnya yang relevan dengan informasi tersebut. Proses menghubungkan tulisan dengan bunyinya sesuai dengan sistem tulisan yang digunakan. Serta kemampuan mengantisipasi makna terhadap baris-baris dalam tulisan. Kegatan membaca bukan hanya kegiatan mekanis saja, melainkan merupakan kegiatan menangkap maksud dari kelompokkelompok kata yang membawa makna.

\section{E. Penyusunan RPP Kurikulum 2013 Berbasis Dialog Islami}

Berdasarkan Surat Edaran Menteri Pendidikan dan Kebudayaan Nomor 14 Tahun 2019 tentang Penyederhanaan RPP dimana RPP hanya terdiri dari 3 komponen yang meliputi: tujuan pembelajaran, langkah-langkah (kegiatan) pembelajaran, dan penilaian pembelajaran (assessment). Guru dapat menyusun, mengembangkan, memilih, memodifikasi dan menggunakan RPP secara bebas dan sederhana sesuai dengan 3 prinsip tersebut diatas. Tujuan dari penyederhanaan RPP ini adalah untuk meringankan beban administratif guru dan memberikan kebebasan kepada guru untuk berkreasi dan berinovasi dalam proses pembelajaran. Oleh karena itu, untuk lebih memudahkan dan memfokuskan implementasi pembelajaran berbasis dialog islami, maka pada penelitian ini mencoba untuk disederhanakan dalam bentuk konkrit berupa RPP merdeka. Adapun bentuk RPP yang digunakan oleh guru Pendidikan Agama Islam di SMAN 71 pada semester 1 (ganjil) Tahun Ajaran 2019-2020 yang dimulai pada 15 juli 2019 hingga 20 Desember 2019. RPP tersebut penulis lampirkan. Kegiatan pembelajaran ini dilakukan di Kelas XII /Semester Ganjil, adapun materi yang menjadi topik bahasan adalah : Q.S. Luqman/31: 13-14 dan Q.S. al-Baqarah/2: 83, yang membutuhkan Alokasi Waktu 2 Minggu x 3 Jam Pelajaran @45 Menit dengan metode Model Pembelajarannya menggunakan model: pembelajaran kolaboratif yaitu: Tematik dengan melihat Mind mapping, Discovery learning, Problem Based Learning (PBL). Metode yang dilakukan

selama pembelajaran adalah metode Tanya jawab, wawancara, diskusi dan dialog interaktif.

1. Tujuan Pembelajaran

Setelah mengikuti proses pembelajaran, peserta didik diharapkan dapat: (1) Meyakini bahwa agama Islam mewajibkan umatnya untuk beribadah dan bersyukur kepada Allah (2) Berbuat baik kepada sesama manusia khususnya kedua orang tua dan guru sesuai dengan perintah Allah dalam Q.S. Luqman/31: 13-14 dan Q.S. al-Baqarah/2: 83, serta Hadis terkait (3) peningkatan Shalat Subuh berjamaah untuk merubah sikap siswa (4) Menjelaskan dan mengidentifikasi Tajwid menelusuri asbabun nuzul, mengidentifikasi maknanya, menjelaskan pesan dan manfaatnya, mengaitkan dengan masalah terkini, mendeokan dan meyajikannya sebagai bekal persiapan diskusi.

2. Langkah-Langkah Pembelajaran 
Pada kegitan ini guru menyiapkan saat pertemuan pertama 3 hal yatu: (1) Orientasi, (2) Aperpepsi (3) motivasi dan (4) Pemberian Acuan. Seperti guru yang lain pada umunya, siswa akan diminta Melakukan pembukaan dengan salam pembuka, memanjatkan syukur kepada Tuhan YME dan berdoa untuk memulai pembelajaran, namun yang membedakannya peneliti disini menanyakan keaktifan shalat subuh untuk diteliti perkembangannya dalam satu semester kemudian menekankan Motivasi, dengan menceritakan hal yang berkaitan dengan tema bahasan, memberikan Acuan, Memberitahukan materi pelajaran yang akan dibahas pada pertemuan saat itu. Memberitahukan tentang mekanisme pelaksanaan pengalaman belajar sesuai dengan langkah-langkah pembelajaran.

Pada Kegiatan Inti Pembelajaran, siswa diberikan simulasi berupa literasi peserta didik diberi motivasi atau rangsangan untuk memusatkan perhatian pada topik materi, cara menentukan topi materi penulis hanya akan melihat tema bersar dari pembelajaran tersebut dari daftar isi buku paket, kemudian mengambil bab-babnya sebagai tema besar dan sub babnya sebagai tema pengembangan, selanjutnya guru mengembangkannya ke dalam bentuk peta konsep (Mind Mappaing) dengan tujuan untuk mengarahkan peserta didik agar tidak keluar topik pembahasan saat mendiscovery materi, kemudian meminta siswa untuk membagi kelompok dalam satu semester, dari kelompok itu guru memberikan tugas dalam satu semester pertema bab dari buku acuan siswa, jadi pertemuan setiap bab pelajaran bisa dilakukan satu hingga 2 pertemuan, kemudian siswa mengexplore dari berbagai sumber seperti buku acuan siswa, internet, kemudian dipresentasikan ke dalam 2 bentuk projek (dalam bentuk powerpoint atau pembuatan video) sesuai minat siswa, setelah mereka mengerjakannya, pada pertemuan berikutnya mereka diminta untuk mempresentasikannya, setelah presentasi selesai siswa kelompok lain diperkenankan bertanya kepada presentator(siswa yang bertugas), dan meletakkan setiap pertanyaannya untuk langsung diketik diakhir powerpoint siswa. Adapun pada penelitian ini penulis hanya menampilkan satu sampel materi pembahasannya yaitu Q.S. Luqman/31: 13-14 dan Q.S. al-Baqarah/2: 83.

Kegiatan ini diharapkan dapat bermanfaat bagi peserta didik dalam mengembangkan soft maupun hard skill seperti berpikir kritis (critical thingking), meningkatkan literasi (literacy enhancement), kerjasama (collaboration), komunikasi (communication), dan kreatifitas (creativity).

3. Penilaian Hasil Pembelajaran

Penilaian hasil belajar peserta didik pada jenjang pendidikan dasar dan menengah didasarkan pada prinsip-prinsip ${ }^{6}$ : (1) Objektif, berarti penilian berbasis pada standar dan tidak dipengaruhi faktor subjektifitas penilai; (2) Terpadu, berarti penilaian oleh pendidik dlakukan secara terencana; (3) Ekonomis, berarti penilaian yang efesien dan

\footnotetext{
${ }^{6}$ Rusman, Pembelajaran Tematik Terpadu, Jakarta: Rajawali Press, Cet.2, 2016, hlm264
} 
efektif dalam perencanaan, pelaksanaan dan pelaporan; (4) Transparan, berarti prosedur penilaian, kriteria penilaian dan dasar pengambilan keputusan dapat diakses semua pihak; (5) Akuntabel, berarti penilaian dapat dipertanggung jawabkan kepada pihak internal sekolah maupun eksternal untuk aspek teknik, prosedur, dan hasil dan (6) Edukatif, berarti mendidik dan memotivasi peserta didik dan guru.

Setelah mengkomparasikan ke 11 indikator dalam berdialog dengan indikatorindikator dalam pembelajaran aktif serta melakukan penulusuran pada pembahasan terkait yang telah lampau. Sekurang-kurangnya dapat ditemukan bahwa:

1) Relevansi dan internalisasi indikator adab berdialog dengan pembelajaran siswa aktif memiliki banyak kesamaan dalam mengungkap indikatornya.

2) Dasar pijakan pembelajaran aktif diperlukan konsep tambahan yaitu 'sumber baca' dari membaca ini ditemukan 3 dasar bacaan, yaitu: (1) membaca secara Teks, (2) membaca secara Konteks, dan (3) membaca Situasional.

3) Teori Fink, yang telah melakukan kajian kritisnya terhadap teori Bloom, lebih banyak mengusung tentang pentingnya dialog, Fink yang telah Mengajukan Lima prinsip Signifikan Lerning untuk memperkuat teorinya. Lima prinsip itu ialah: (1)Memberi tantangan belajar kepada students.(Challenge students to significant kinds of learning), (2) Menggunakan bentuk pembelajaran yang aktif. (Use active forms of learning), (3) Memiliki guru/dosen yang peduli terhadap: materi peserta didik, dan terhadap proses pengajaran dan pembelajaran. (Have teachers who care-about the subject, their students, and about teaching and learning [not just research].) (4) Memiliki guru/dosen yang dapat berinteraksi baik dengan students. (Have teachers who interact well with students) (5)Memiliki system feedback (evaluasi), assessment (ujian), dan grading (pemberian nilai) yang baik. (Have a good system of feedback, assessment, and grading.), hingga akhirnya mengenalkan 6 macam taksonomi pembelajaran tersebut ternyata setelah ditelusuri akarnya juga memiliki padanan dengan kaidah adab berdialog yang diusung Muhammad T\{ant\{awi, sehingga sama mengeructnya untuk dapat ditambahkan 'sumber bacaan' di dalam taksonominya.

4) Bahwa konstruksi dasar dalam berdialog pada poin 3 pada pembahasan bab IV menunjukkan pentingnya memberikan dalil yang akurat dalam berdialog, sedangkan dalam taraf pembelajaran hal ini disebut sebagai 'sumber bahan ajar yang valid' maka hal tersebut dirasa perlu untuk di-internalisasikan kedalam indikator pembelajaran siswa aktif.

5) Bentuk formulasi RPP model pembelajaran siswa aktif berbasis dialog islami.

6) Perlunya penilaian (assesment) konkrit untuk memonitoring perkembangan siswa dalam pembelajaran aktif. Saat proses penilaian ditemukan 2 tipikal siswa pembelajar secara garis besar terbagi menjadi siswa yang belajar berdasarkan nilai/kinerja (siswa entitas), dan siswa yang belajar untuk pembelajaran itu sendiri (inkremental), terbukti bahwa siswa inkrimental memiliki semangat keingin tahuan yang tinggi dibanding siswa entitas, 
meskipun siswa entitas masuk pada kategori kelas yang diunggulkan yaitu kelas MIPA. hal ini berkesesuaian dengan teori yang diusung oleh seorang profesor bidang prsikolog 'Carol J. Dweck' yang telah melakukan penelitian ini dan menuliskannya ke dalam buku "Self Theories" dan diterbitkan terjemahannya pada tahun 2020 ini.

7) Dialog Interaktif dengan siswa dapat dilakukan dimanapun, dan ditemukan juga bahwa siswa yang Shalat Subuh Berjamah memiliki semangat dan etos belajar yang tinggi di Sekolah.

8) Dengan melakukan assesment digital melalui aplikasi WPS berupa excel dalam Hanphone, dapat dilakukan berinteraksi dan berdialog dengan lebih aktif, efisien dan efektif baik dengan peserta didik maupun Stakeholder terkait.

9) Diperlukannya penelitian lanjutan untuk memformulasikan teori dan re-implementasi mengenai pembelajaran siswa aktif berbasis dialog islami ini.

\section{Kesimpulan}

Berdasarkan hasil dan pembahasan sebagaimana telah dikemukakan dalam penelitian ini, maka terdapat beberapa kesimpulan yang dapat diambil, diantaranya adalah adab berdialog (Adab Hiwar fi al-Islam) menurut Muhammad Sayyid Thanthawi dalam karya populer yang membahas mengenai adab berdialog, terutama dalam mengejawentahkan praktek dialogis secara konkrit, dengan perincian ke 11 (sebelas) kaidah adab berdialog yang esensial tersebut, setidaknya etika-dialogis antar personal dapat dikonstruksikan melalui kaidah berikut: (1) Berasaskan kejujuran, (2) Fokus pada tema yang dibahas, (3) Menghadirkan dalil akurat dan logika sehat (4) Memperjelas letak perbedaan secara konkrit dan benar sesuai pembahasan (5) Etika kesantunan, menghindari perbuatan yang tidak layak untuk diperbuat, (6) Mengarah pada kepentingan umum, (7) Mendahulukan pendapat para ahli, (8) Tidak menjeneralisir hukum, (9) Meninjau kembali asas manfaat dan madharatnya, (10) Mengupgrade pemahaman dan akurasi hukum yang disepakati para ahli (11) Bersifat terbuka dan apa adanya, dengan mengedepankan kebenaran. Sebelas kaidah diatas merupakan hasil dari kajian tafsir al-Qur'an Muhammad sayyid Thanthawi yang mendalam dengan dihadirkannya berbagai dalil al-Qur'an dan Hadis yang logis dan menarik dalam pemaparannya.

Pemikiran Muhamad Sayyid Thanthawi tentang adab berdialog ini ternyata dapat diimplementasikan secara strategis-konseptual ke dalam pembelajaran aktif di sekolah dimana salah satunya adalah melalui Rencana Perangkat Pembelajaran (RPP) dengan menginternalisasikan dasar pijakan pembelajaran aktif yang diusung oleh L. Dee Fink, setelah mengkritisi taksonomi Bloom dengan mengusung 6 hal Significant Learning yaitu: (1) Dimensi Pengetahuan Dasar: yang meliputi memahami dan mengingat.; (2) Dimensi Penerapan: Berpikir kritis, kreatif dan praktis; memecahkan masalah. (3) 
Dimensi Penyatuan: menghubungkan antar ide, gagasan, subyek dan orang; (4) Dimensi Kemanusiaan: belajar tentang dan perubahan diri seseorang, memahami dan berinteraksi (5) Dimensi Kasih sayang: mengidentifikasi/perubahan perasaan, kepentingan dan nilai-nilai seseorang. Kata kerjanya adalah: refleksi dan interpretasi; (6) Dimensi Belajar untuk belajar: belajar bagaimana menjawab dan bertanya, menjadi pembelajar yang memiliki self-directed. Kata kerjanya adalah mengkritisi dan menganalisis. Ke-enam konsep yang menjadi dasar filosofis pembelajaran aktif setelah diselaraskan dengan 11 kaidah adab berdialog Imam T\{ant\{awi>, ditemukan sisi-sisi kesamaan yang signifikan dan perlu adanya tambahan pada dasar filosofi pembelajaran aktif berbasis dialogis ke dalam Rencana Perangkat Pembelajaran (RPP) merdeka secara sistematis, konsep tambahan yang dimaksud adalah dimensi 'sumber baca'. Dari landasan filosofi berupa 'sumber baca' inilah penulis menemukan 3 konsep membaca, yaitu: (1) Membaca Teks yang tesurat, (2) Membaca secara Konteks (tersirat), dan (3) Membaca Situasional (memahami secara seksama kondisi dan keadaan yang tengah berlangsung di dalam proses pembelajaran dengan baik dan benar). Hal ini menjadi temuan yang urgent untuk ditambahkan ke dalam landasan filosofi pembelajaran aktif berbasis dialogis.

\section{Daftar Pustaka}

Al-Baqi, A \& Muhammad Fu'ad. (1996). Mu'jam al-Mufahras li al-Fazi alQur'a al-Karim, Dar al al-Fikr, Al-Qahirah.

Al-Attas. (1997). Aim and Objectives os Islamic Education, Jeddah: King Abdul Aziz University.

Al-Attas. (1997). Muhammad Naquib. Islam dan Sekularisme, Bandung: Pustaka, 1981.

Al-Jaziri, M. An-Nihayah fi gharibi al-Hadis wa al-Atsar, Ibn Atsir, 554-606 H, vol.1.

Al-Mishri, Muhammad ibn Mukarrim ibn Manzur al-Ansari al-Ifriqi, 'Amir Ahmad Haidar dan 'Abd al-Mun'im Khalil Ibrahim. (2009). Lisan al-'Arab, ed'. Beirut: Dar al-Kutub al-'Ilmiyyah.

Al-'Uwaidah, Salman ibn Fahd. (1991). Dawabit li al-Dirasat al-Fiqhiyyah, Riyyadh: Dar alWatan.

Alwasilah, A. Chaedar. (2012). Pokoknya Kualititatif: Dasar-dasar Merancang dan Melakukan Penelitian Kualitatif, Bandung: PT Dunia Pustaka Jaya dan Pustaka jaya Jakarta.

Amri, Sofian. (2015). Implementasi Pembelajaran aktif dalam Kurikulum 2013, Jakarta: Prestasi Pustaka Jakarta.

Arikunto, Suharsimi. (2010). Prosedur Penelitian: Suatu Pendekatan Praktik, Jakarta: PT Rineka Cipta.

Azra, Azyumardi. (2012). Pendidikan Islam: Tradisi dan Modernisasi di Tengah Tantangan Milenium III, Jakarta: Kencana.

Az Zubaidi, Imam Ahmad ibn Abdil. (1994). Mukhtar Shahih Bukhari, Beirut: Darrul Kutub. 
Bungin, Burhan. (2003). Analisis Data Penelitian Kualitatif, Jakarta: PT. Raja Grafindo Persada.

Dalman. (2014). Keterampilan Membaca, Jakarta: Rajawali Pers.

Depertemen Bahasa 'Arab. (2005). Mu'jam al-Wasit, Jumhuriyyah al-Misriyyah: Maktabah al-Syaruq ad-Dauliyyah.

Departemen Pedidikan Nasional. (2012). Kamus Besar Bahasa Indonesia Pusat Bahasa: Edisi Keemat, Jakarta: PT Gramedia Pustaka Utama.

Dimyati \& Mudjiono. (2009). Belajar dan Pembelajaran, Jakarta: Rineka Cipta.

Dweck, Carol S. (2000). Self-theories: Their role in motivation, personality, and development. Psychology press.

Gall, Meredith Damien, Joyce P. Gall dan Walter R.Borg. (2003). Educational Research: An Introduction, Boston: Pearson Education Inc.

Hefni, Harjni. (2015). Komunikasi Islam, Jakarta: Kencana.

Humaid, Ibn, et.al, Mausu'ah Nadrah al-Na'im fi Makarim akhlaq al-Rasul al-Karim, vol.2.

Ibn Mandhūr, M. (1988). Lisan al-arab. Juz V, Beirut: Dar Al-Kutub al-Ilmiyyah.

Kemenristek Dikti. Bentuk dan Metode Pembelajaran Abad 21.

Kesuma, Triatna, \& Permana. (2011). Pendidikan Karakter : Kajian Teori dan Praktik di Sekolah, hlm.24; dan Sauri, Filsafat dan Teosofat Akhlak.

Kridalaksana, Harimurti. (1985). Tata bahasa deskriptif bahasa Indonesia: Sintaksis. Vol. 85. Pusat Pembinaan dan Pengembangan Bahasa, Departemen Pendidikan dan Kebudayaan.

Moleong, Lexy J. (2013). "Metode penelitian kualitatif (Revisi)." Bandung: PT. Remaja Rosdakarya.

Ma'luf, Louis. (1986). al-Munjid fi al-Lughah wal-A'lam, Beirut: Dâr al-Masyriq.

Maqbul, Ali Muhammad. (2008). Manahij al-Bahst al-'ilmi wa tahqiq al-turats, Alexandria: Dar al-iman dan Dar al-Quds Shan'a.

McKeachie, W. W. (1986). Teaching Tips: A Guidebook for the Beginning College Teacher. Boston: D.C.Health.

Munawwir, A.W. (2007). Kamus Al-Munawwir Indonesia Dan Arab, Surabaya: Pustaka Progressif.

McKeachie, W. W. (1986). Teaching Tips: A Guidebook for the Beginning College Teacher. Boston: D.C.Health.

McKeachie, W. W. (1986). Teaching Tips: A Guidebook for the Beginning College Teacher. Boston: D.C.Health.

Nazir, Moh. (2011). Metode Penelitian, Jakarta: Ghalia Indonesia.

Pollio, H.R. (1984). What Student Think abaut and Do in College Lecture Classes, dalam Teaching Learning issues No.53, Knoxville: Learning Research Centre, University of Tennesse.

Ramayulis. (2002). Ilmu Pendidikan Islam, Jakarta: Kalam Mulia.

Rosyada, Dede. (2004). Paradigma Pendidikan Demokratis: Sebuah Model Pelibatan Masyarakat Dalam Menyelenggarakan Pendidikan, Jakarta: Prenada Media.

Rusman. (2006). Pembelajaran Tematik Terpadu, Jakarta: Rajawali Press, Cet. 2.

Santrock, John W., and John W. Santrock. (2007). "Psikologi Pendidikan edisi kedua."

Sauri, S., \& Tafsir, A. (2011). Filsafat dan Teosofat Akhlak. 
Sugiyono. (2012). Metode Penelitian Kuantitatif, Kualitatif dan R \& D, Bandung: Alfabeta. Sulastini, Rita. (2018). "Reposisi Filosofi Pendidikan Dalam Proses Pembelajaran." INSANIA: Jurnal Pemikiran Alternatif Kependidikan 23, no. 1.

Syafi'I, Imam. (1999). Pengajaran Membaca Terpadu. Bahan Kursus Pendalaman Materi Guru Inti PKG Bahasa dan Sastra Indonesia. Malang: IKIP.

Tafsir, Ahmad. (2014). Filsafat Pendidikan Islami, Bandung: PT. Remaja Rosdakarya, Cet.6.

Tafsir, Ahmad. (1991). Ilmu Pendidikan Dalam Perspektif Islam, Bandung: Remaja Rosdakarya.

Winkel, W. S. (1987). Psikologi Pengajaran, Jakarta: Gramedia.

Yaumi, Muhammad. (2013). Prisip-Prinsip Desain Pembelajaran,Jakarta: Kencana.

http://www.nwlink.com/ donclark/hrd/learning/active.html diakses pada tanggal: 08 maret 2020. 